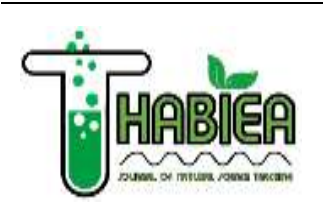

\author{
Thabiea: Journal of Natural Science Teaching \\ Program Studi Tadris Ilmu Pengetahuan Alam \\ Institut Agama Islam Negeri Kudus \\ http://journal.stainkudus.ac.id/index.php/Thabiea \\ p-issn: 2580-8974, e-issn: 2655-898x
}

\title{
Analisis Penerapan Pembelajaran Kimia Organik Berkonteks Isu Sosiosainstifik untuk Meningkatkan Literasi Sains Mahasiswa IPA
}

\author{
Ullum Miftaqul Zannah Gustita'iroh ${ }^{\mathrm{a}, 1^{*} \text {, Siti Aslihatu Rohmah }}{ }^{\mathrm{b}, 2}$, Faiq Makhdum Noor ${ }^{\mathrm{c}, 3}$ \\ ${ }_{\text {a,b,c }}$ Institut Agama Islam Kudus, Jalan Conge Ngembalrejo No. 51 Kec. Bae, Kab. Kudus, Jawa Tengah, 59322 \\ ${ }^{1}$ ulummiftahul11.@gmail.com*; ashlihaturrohmah29@gmail.com; faiq@iainkudus.ac.id
}

\begin{tabular}{|c|c|c|}
\hline Informasi artikel & & ABSTRAK \\
\hline $\begin{array}{l}\text { Kata kunci: } \\
\text { Pembelajaran } \\
\text { organik } \\
\text { Isu sosiosainstifik } \\
\text { Literasi sains }\end{array}$ & kimia & $\begin{array}{l}\text { Ilmu pengetahuan dan teknologi terus berkembang dengan pesat, hal ini ditandai } \\
\text { dengan pembaruan ilmu-ilmu sains. Kimia Organik merupakan salah satu mata } \\
\text { kuliah sains yang kurang disenangi dan dipandang sulit oleh mahasiswa karena } \\
\text { bersifat tidak berwujud. Tantangan pembelajaran mata kuliah kimia organik yaitu } \\
\text { meningkatkan literasi saintifik mahasiswa. Rendahnya literasi saintifik mahasiswa } \\
\text { di Indonesia disebabkan oleh proses belajar mengajar yang masih berorientasi pada } \\
\text { penguasaan konsep sains melalui proses presentasi dan diskusi. Tujuan dari } \\
\text { penelitian ini yaitu menganalisis respons mahasiswa terhadap penerapan } \\
\text { pembelajaran kimia organik dengan cara diskusi dan berargumentasi tentang isu-isu } \\
\text { sosiosainstifik untuk meningkatkan literasi sains mahasiswa tadris IPA. Penelitian } \\
\text { dilakukan di jurusan Tadris IPA B IAIN Kudus angkatan } 2017 \text { yang melibatkan } 36 \\
\text { mahasiswa. Metode yang digunakan dalam penelitian ini ialah metode deskriptif,. } \\
\text { Pendekatan yang digunakan ialah pendekatan kualitatif. Pengambilan data melalui } \\
\text { analisis sesuai kebutuhan, observasi dan wawancara. Penelitian ini mengungkapkan } \\
\text { bahwa } 85 \% \text { mahasiswa pendidikan IPA setuju bahwa pembelajaran berkonteks isu } \\
\text { sosiosainstifik pembelajaran yang menarik. 75\% setuju bahwa pembelajaran kimia } \\
\text { organik berkonteks isu sosiosainstifik dapat mempermudah pemahaman isi materi. } \\
90 \% \text { setuju bahwa pembelajaran berkonteks isu sosiosainstifik meningkatkan literasi } \\
\text { ilmiah. Pembelajaran mata kuliah kimia organik melalui diskusi dan argumentasi } \\
\text { terkait isu-isu sosiosainstifik dapat meningkatkan literasi sainstifik mahasiswa. }\end{array}$ \\
\hline
\end{tabular}

Key word:

Learning organic chemistry

Socioscientific issues Scientific literacy

\section{ABSTRACT}

Science and technology continues to grow rapidly, this is marked by the renewal of science. Organic Chemistry is one of the subjects of science that is less favored and considered difficult by students because it is virtual. The challenge of learning organic chemistry courses is how to improve student scientific literacy. The low level of scientific literacy of students in Indonesia is caused by the teaching and learning process which by still oriented to mastering the scientific concepts through the process of presentation and discussion. The purpose of this research is to analyze student responses to the application of the learning of organic chemistry by way of discussion and argumentation on socioscientific issues to improve students' scientific literacy. The research was conducted in the Department of Science and Technology Kudus IAIN class-B of 2017 involving 36 students. The method used in this research is descriptive method. The approach used is a qualitative approach. Retrieval of data through analysis as needed, observation and interviews. This research reveals that $85 \%$ of science education students agree that learning is in context of interesting sociocritical learning issues. $75 \%$ agreed that learning organic chemistry in the context of sociocultural issues could facilitate understanding the content of the material. $90 \%$ agree that learning in context of sociocultural issues enhances scientific literacy. Learning organic chemistry courses through discussion and argumentation related to sociocultural issues can improve student scientific literacy.

Copyright @ 2019 Institut Agama Islam Negeri Kudus. All Right Reserved 
Pendahuluan

Ilmu pengetahuan teknologi dan informasi terus berkembang tanpa batas seiring dengan kemajuan zaman. Pendidikan sains memiliki potensi yang besar untuk menciptakan sumber daya manusia yang berkualitas dalam mengahadapi era industrialisasi dan globalisasi. Potensi tersebut dapat terwujud jika pendidikan sains dapat melahirkan mahasiwa yang cakap dalam bidangnya dan memiliki kemampuan berpikir logis, kritis, kreatif, mampu memecahkan masalah dan menguasai teknologi yang terus berkembang. Berpikir logis dan kritis merupakan kemampuan yang wajib dimiliki mahasiswa, karena mahasiswa harus kritis terhadap isu-isu global yang muncul. Berfikir kreatif merupakan cara berfikir yang dipenuhi dengan ide atau gagasan dalam mengembangkan daya imajinasi. Berfikir kreatif adalah kemampuan mendayagunakan potensi yang dimiliki yang muncul dari berbagai keadaan. Kemampuan yang harus dimiliki mahasiswa yang paling utama yaitu mampu memecahkan masalah (Bani, 2016). Permasalahan saat ini yang harus diselesaikan diantaranya perubahan iklim, ketersedian pangan, ketahanan lingkungan, kesehatan dan krisis energy (Haris, 2013). Kemampuan menyelesaikan masalah berdasarkan penguasaan sains disebut literasi sains (Turiman, 2012).

Literasi sains merupakan kemampuan memecahkan masalah yang didasari pada pemahaman sains, pengkomunikasian, serta penerapannya yang juga berdampak pada sikap peka dan peduli terhadap lingkungan (Toharudin, 2011). Literasi sains merupakan salah satu kompotensi yang sangat penting dikuasai oleh setiap individu karena dapat membantu beradaptasi terhadap tantangan global (Holbrook, J, \& Rannikmae, 2009), serta dapat meningkatkan daya saing negara berbasis pengetahuan. Upaya untuk melatih individu agar memiliki daya saing tinggi dapat dimulai melalui jalur pendidikan (Bani, 2016). Pendidikan dapat mengakomodasi pengembangan literasi sains secara merata apabila setiap individu mendapat kesempatan yang sama untuk memperoleh kualitas pendidikan terbaik.

Mahasiswa yang berliterasi sains berarti mahasiswa tersebut memiliki pengetahuan dan memahami konsep-konsep dan proses ilmiah yang diperlukan untuk membuat keputusan, mampu menyadari dan berpartisipasi secara aktif dalam diskusi serta memiliki rasa peduli dan mampu membuat keputusan terhadap isu-isu yang terjadi di masyarakat dan dunia secara global. Kebijakan wajib belajar pendidikan dasar sembilan tahun merupakan kebijakan yang terkait dengan standar minimal mutu sumber daya manusia. Dengan kebijakan pemerintah tersebut diharapkan semua masyarakat Indonesia akan memiliki literasi sains (Hidayat, 2007).

Pembelajaran sains khususnya saat ini bukan hanya menekankan pemahaman konsep saja, tetapi mahasiswa juga dituntut untuk dapat menerapkan konsep sains untuk memecahkan masalah yang terkait sains dalam kehidupan sehari-hari. Jadi, manfaat keberhasilan pembelajaran sains akan lebih terasa jika yang diperoleh dari pembelajaran dapat diaplikasikan dalam realitas kehidupan. Seperti halnya literasi sains merupakan pengetahuan ilmiah seseorang dan penggunaan pengetahuan tersebut untuk mengidentifikasi pertanyaan, 
untuk mendapatkan pengetahuan baru untuk menjelaskan fenomena ilmiah, dan menarik kesimpulan yang dapat di ekstrak mengenai isu-isu terkait sains, pemahaman tentang ciri khas sains sebagai bentuk pengetahuan manusia dan penyelidikan, kesadaran, tentang bagaimana sains dan teknologi membentuk lingkungan material, intelektual, dan budaya, dan kemauan untuk terlibat dalam isu-isu terkait sains dan dengan gagasan sains sebagai warga negara reflektif.

Hasil penilaian literasi saintifik oleh PISA 2012 menempatkan siswa Indonesia dalam urutan 64 dari 65 negara yang berpartisipasi dalam asesmen tersebut. Hasil asesmen literasi saintifik oleh TIMSS (Trends in International Mathematics and Science Study) pada 2011 juga menempatkan Indonesia berada di peringkat ke 40 dari 42 negara yang berpartisipasi. Berdasarkan hasil penilaian tersebut maka perlu menempatkan literasi saintifik menjadi tujuan pendidikan sains yang penting.

Rendahnya literasi saintifik siswa di Indonesia disebabkan oleh proses belajar mengajar yang masih berorientasi pada penguasaan konsep sains melalui proses presentasi-diskusi. Dalam pembelajaran kimia organik di Indonesia ditemukan bahwa dosen cenderung menjelaskan dan memberikan informasi tentang konsep kimia organik secara verbal dan tidak mengajak mahasiswa melakukan observasi. Dosen cenderung menjelaskan topik menggunakan metode ceramah.

Pembelajaran kimia organik mengupayakan terbentuknya subyek didik sebagai manusia yang memiliki modal literasi sains yaitu manusia yang membuka kepekaan diri, mencermati, menyaring, mengaplikasikan, serta turut serta berkontribusi bagi perkembangan sains dan teknologi untuk peningkatan kesejahteraan dan kemaslahatan masyarakat. Pembelajaran kimia seharusnya dapat menghubungkan konsep-konsep yang bersifat mikroskopik dan simbolik dengan dimensi makroskopik yang merupakan realita yang terjadi di sekitar peserta didik (Imaduddin, 2018; Imaduddin \& Haryani, 2019). Rendahnya literasi sains mahasiswa Indonesia salah satunya disebabkan oleh proses pembelajaran yang terjadi di kelas yang kurang melibatkan proses sains dan kurang membelajarkan berpikir tingkat tinggi. Solusi untuk meningkatkan literasi saintifik mahasiswa adalah penerapan strategi pembelajaran yang mengembangkan keterampilan berpikir tingkat tinggi dan pemecahan masalah melalui pendekatan multidisiplin.

Pembelajaran yang melatih kemampuan pemecahan masalah adalah Problem-Based Learning atau Pembelajaran Berbasis Masalah (PBM). PBM membantu siswa menjadi pebelajar mandiri (Arend, 2012). Mahasiswa akan membuat hubungan yang kuat antara konsep dan fakta yang dipelajari sehingga mahasiswa aktif bekerja untuk mencari informasi, tidak hanya sebagai pebelajar pasif yang hanya menerima informasi. Pembelajaran berbasis Socio-Scientific Issues (SSI) merupakan perluasan dari pendekatan Science, Technology, and Society (STS) dan Problem-based approaches yang menempatkan konten sains pada konteks sosial untuk memberikan peserta didik suatu pandangan bagaimana sains berhubungan dengan dunia nyata (Imaduddin \& Khafidin, 2018). Hal 
ini diharapkan mahasiwa dapat lebih kritis, dapat lebih sensitiv terhadap isu-isu global dan yang paling penting dapat meningkatkan literasi sains mahasiswa IPA.

Penelitian ini bertujuan untuk mengetahui respon mahasiwa yang telah diajar dengan menggunakan metode pembelajaran berbasis isu sosiosaintifik memiliki literasi sains yang baik. Data yang dikumpulkan dalam penelitian ini meliputi:

$$
\text { pendapat-pendapat }
$$

tentang pembelajaran kimia organik berbasis isu sosiosentifik; (2) metode yang relevan untuk model pembelajaran kimia organik berbasis isu sosiosainstifik. Pengambilan data melalui analisis sesuai kebutuhan, observasi, wawancara. Manfaat dari penelitian ini adalah memberikan rekomendasi penggunaan isu-isu sosiosainstifik sebagai konteks masalah dalam penerapan pembelajaran berbasis isu dalam pembelajaran kimia organik.

\section{Metode penelitian}

Metode yang digunakan dalam penelitian ini ialah metode deskriptif,. Pendekatan yang digunakan ialah pendekatan kualitatif. Subyek dalam penelitian ini ialah mahasiswa tadris IPA B IAIN Kudus. Data yang dikumpulkan dalam penelitian ini meliputi: (1) pendapat-pendapat tentang pembelajaran kimia organik berbasis isu sosiosentifik; (2) metode yang relevan untuk model pembelajaran kimia organik berbasis isu sosiosainstifik. Pengambilan data melalui analisis sesuai kebutuhan, observasi, wawancara.

\section{Hasil dan pembahasan}

Pembelajaran sains seharusnya mempelajari pengetahuan (sejarah alam dan ekologi, isu-isu lingkungan dan permasalahannya, sosial-politik ekonomi), keterampilan, afektif (faktor-faktor yang mempengaruhi perilaku yang bertanggung jawab terhadap lingkungan sekitar) sebagai komponen dan subkomponen literasi sains. Jurusan Tadris IPA ada mata kuliah kimia organik. Penerapan pembelajaran mata kuliah kimia organik dengan pendekatan kontekstual dilakukan berdasarkan analisis kebutuhan. Deskripsi pembelajaran mata kuliah kimia organik mempunyai karakteristik.

Tabel 1. Karakteristik mata kuliah kimia organik dengan pendekatan kontekstual

\begin{tabular}{|c|c|c|}
\hline No. & Karakteristik & Uraian \\
\hline 1. & Kajian & $\begin{array}{l}\text { Isu sosiosainstifik terkait } \\
\text { dengan alkohol, } \\
\text { pemanfaatan bahan bakar } \\
\text { dan narkoba. }\end{array}$ \\
\hline 2. & Pendekatan & $\begin{array}{l}\text { Pendekatan kontekstual } \\
\text { yang efektif terintegrasi } \\
\text { dengan pembelajaran } \\
\text { mata kuliah kimia } \\
\text { organik dan isu-isu sosial } \\
\text { terkait materi yang } \\
\text { disampaikan. }\end{array}$ \\
\hline 3. & Kajian & 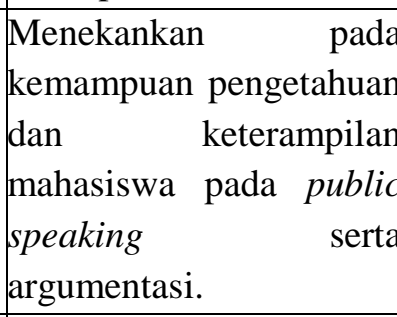 \\
\hline 4. & $\begin{array}{l}\text { Tujuan } \\
\text { evaluasi }\end{array}$ & $\begin{array}{l}\text { Meningkatkan } r \text { literas } \\
\text { sains dan } \\
\text { argumentasi mahasiswa. }\end{array}$ \\
\hline
\end{tabular}

Dari tabel 1 tersebut dapat dilihat bahwa mata kuliah kimia organik dengan pendekatan kontekstual memiliki beberapa karakteristik sebagai berikut, Pertama, kegiatan pembelajaran mengkaji isu-isu sosiosainstifik yang berhubungan dengan konsep alkohol, bahan bakar dan narkoba. Kedua, mata kuliah kimia organik dengan 
pendekatan kontekstual sangat efektif karena terintegrasi dengan isu-isu soasial. Ketiga, fokus pembelajaran menekankan pada kemampuan pengetahuan dan keterampilan mahasiswa pada public speaking serta argumentasi yang berkualitas. Keempat, hasil akhir ditunjukkan untuk meningkatkan literasi sains dan kualitas argumentasi mahasiswa terkait dengan polemik yang disajikan.

Pembelajaran kimia organik dengan isu-isu sosiosainstifik yang terkait dengan konsep pembelajaran dan permasalahannya, keterampilan kognitif, afektif dan tindakan diitegrasikan untuk meningkatkan literasi sains serta kualitas argumentasi. Pembelajaran ini diterapkan pada jurusan Tadris IPA B angkatan 2017. Hasilnya menunjukkan bahwa kualitas pembelajaran mendapatkan kategori baik, hal ini sesuai dengan tanggapan mahasiswa.

Tabel 2. Tanggapan mahasiswa terkait dengan pembelajaran dengan isu-isu kontekstual

\begin{tabular}{|l|l|c|c|}
\hline No. & \multicolumn{1}{|c|}{ Pernyataan } & Ya & Tidak \\
\hline 1. & $\begin{array}{l}\text { Menurut anda } \\
\text { pembelajaran kimia } \\
\text { oraganik berkonteks isu } \\
\text { sosiosainstifik } \\
\text { merupakan } \\
\text { pembelajaran yang } \\
\text { menarik? }\end{array}$ & $85 \%$ & $15 \%$ \\
\hline 2. & $\begin{array}{l}\text { Apakah menurut anda } \\
\text { pembelajaran kimia } \\
\text { organik berkonteks isu } \\
\text { sosiosainstifik dapat } \\
\text { mempermudahran } \\
\text { pemahaman isi materi? }\end{array}$ & $75 \%$ & $25 \%$ \\
\hline 3. & $\begin{array}{l}\text { Apakah dengan adanya } \\
\text { pembelajaran } \\
\text { berkonteks } \\
\text { sosiosainstifik anda } \\
\text { sering membaca artikel } \\
\text { ilmiah terkait dengan } \\
\text { materi? }\end{array}$ & $90 \%$ & $10 \%$ \\
\hline
\end{tabular}

Pada tabel 2 menunjukkan tanggapan mahasiswa Tadris IPA B angkatan 2017 mengenai pembelajaran kimia organik berkonteks isu-isu sosiosainstifik. Tanggapan tersebut menunjukkan antusias yang baik terhadap pembelajaran yang diterapkan. Karena dengan penerapan isuisu sosiosainstifik dapat menarik perhatian mahasiswa dalam memahami materi, serta yang paling utama menumbuhkan kesadaran mahasiswa untuk membaca artikel ilmiah dan penelitian. Sehingga dapat meningkatkan literasi sains mahasiswa.

\section{Simpulan}

Kesimpulan dari penelitian ialah pembelajaran kimia organik berkonteks isu sosiosainstifik, mendapatkan respon yang sangat baik oleh mahasiswa. Hal ini dapat terlihat pada hasil penelitian yang menunjukkan bahwa $85 \%$ mahasiswa pendidikan IPA setuju bahwa pembelajaran kimia organik berkonteks isu sosiosainstifik adalah pembelajaran yang menarik. $75 \%$ setuju bahwa pembelajaran kimia organik berkonteks isu sosiosainstifik sangat memudahkan mahasiswa dalam memahami materi. 90\% setuju bahwa pembelajaran kimia organik berkonteks isu sosiosainstifik dapat meningkatkan literasi sains mahasiswa.

\section{Referensi}

Arends, R I. (2012). Learning To Teach 9th Edition. New York: Mc Graw-Hill.

Bani, S. (2016). Tantangan Lembaga Pendidikan Di Tengah Persaingan Global. 05(02).

Haris, J.M. 2013. Population, Resorurces and Energy in The Global Economy: 
Ullum Miftaqul Zannah Gustita'iroha, dkk | Analisis Penerapan Pembelajaran Kimia.. .

a Vindication of Herman Daly's Vision. Medford USA: Global Development And Environment Institute.

Hidayat, I. 2007. Peranan Keyakinan Guru Terhadap Hakikat Dan Belajar Mengajar Saina Terhadap Pengembangan Profesionalisme. Cakrawala, 27(1).

Imaduddin, M., \& Khafidin, Z. (2018). Ayo Belajar IPA dari Ulama: Pembelajaran Berbasis SosiScientific Issues di Abad ke-21. Thabiea: Journal of Natural Science Teaching, 01(02), 102-120.

Imaduddin, M. (2018). Analisis Miskonsepsi Submikroskopik Konsep Larutan pada Calon Guru Kimia. Edu Sains: Jurnal Pendidikan Sains \& Matematika, 6(2), https://doi.org/10.23971/eds.v6i2.98 3

Imaduddin, M., \& Haryani, S. (2019). Lembar Kerja Directed Activities Related to Texts (DARTs) Bermuatan Multipel Level Representasi untuk Meningkatkan Kemampuan Berpikir Kritis Calon Guru Kimia. Jurnal Inovasi Pendidikan Kimia, 13(1), 22542267.

Holbrook, J, \& Rannikmae, M. 2009. The Meaning of Scientific Literacy. International Journal Of Environmental \& Science Education.

Toharudin, Dkk. 2011. Membangun Literasi Sains Peserta Didik. Bandung: Humaniora.

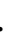

Turiman, Dkk. 2012. Fostering The 21st Century Skill Through Scientific Literacy And Science. 